\title{
The Concept of Philosophy in Post-Apartheid Western Historical Overviews of South African Old Testament Scholarship
}

JACO GERICKE (NORTH-WEST UNIVERSITY)

\begin{abstract}
This article seeks to clarify the concept of "philosophy" as it appeared within popular overviews of South African Old Testament scholarship published in the post-apartheid era. After providing a typology of related research, the discussion proceeds with the identification of the words "philosophy"/"philosophical" in the associated colonialist scholarly discourses. The latter part involves a brief classification, commentary and critique of the metaphilosophical assumptions supervening on the associated intra- and cross-disciplinary contexts.
\end{abstract}

"The secret of theory is that truth does not exist."

KEYWORDS: Old Testament, South African perspectives, histories of interpretation, post-apartheid era, meta-philosophy

\section{A INTRODUCTION}

Historical overviews of Old Testament (OT) scholarship in South Africa are encountered in a variety of research contexts and formats. These include, among others, the following types of historical overviews:

1) Large-scale studies of a distinctive period in the history of the OTSSA $;^{2}$

2) Critical appraisals or corrective and justifying responses to $(1){ }^{3}$

* Submitted: 06/06/2018; peer-reviewed: 06/08/2018; accepted: 12/08/2018. Jaco Gericke, "The Concept of Philosophy in Post-Apartheid Western Historical Overviews of South African Old Testament Scholarship," OTE 31 no. 2 (2018): 299-322. DOI: https://doi.org/10.17159/2312-3621/2018/v31n2a3.

1 Jean Baudrillard, Forget Foucault (Trans. Nicole Dufrense; Cambridge, MA: Semiotext(e), 2007 [1976]), 120.

2 E.g. Jurie H. Le Roux, A Story of Two Ways: Thirty Years of Old Testament Scholarship in South Africa (Pretoria: Verba Vitae, 1993).

3 E.g. James A. Loader, "Die weg van die Here in die woestyn, oftewel God se grootpad in die wildernis: oor A Story of Two Ways," Skrif en Kerk 15/2 (1994): 391413. DOI: https://doi.org/10.4102/ve.v15i2.1105; Jurie H. Le Roux, "Die Kontoere van 'n weerwoord." $V E$ 16/1 (1995): 82-101. 

3) Subsequent supplementation to (1), in some form or another; ${ }^{4}$
4) Taking stock of local reflection on exegetical methods; ${ }^{5}$
5) Local perspectives on a particular theme/approach; ${ }^{6}$
6) A particular scholar's contributions; ${ }^{7}$
7) Critical comparisons of scholarly contributions; ${ }^{8}$
8) OT scholarship vis-à-vis other theological disciplines; ${ }^{9}$
9) OT scholarship at a particular university; ${ }^{10}$
10) OT interpretation in a particular church tradition. ${ }^{11}$

4 E.g. Hendrik L. Bosman, “Ants, spiders or bees . . . and ticks? A typology of Old Testament scholarship in South Africa since 1994 within its African context," OTE 28/3 (2015a): 636-654. DOI: https://doi.org/10.4102/hts.v70il.2641.

5 E.g. Ferdinand E. Deist, "South African Old Testament studies and the future," OTE 7/4 (1994a): 33-51; Alphonso Groenewald, "Once again methods: Is there a method in the madness?" OTE 17/4 (2004): 544-559 and "Changing paradigms: Old Testament scholarship between synchrony and diachrony," in South African Perspectives on the Pentateuch between Synchrony and Diachrony (eds. Jurie H. Le Roux \& Eckart Otto (New York: T\&T Clark, 2007), 108-123.

6 E.g. Willie S. van Heerden, "Taking Stock of Old Testament scholarship on environmental issues in South Africa: The main contributions and challenges," OTE 22/3 (2009): 695-718.

7 Hans J. M. van Deventer, "Eerder anders as elders: Gerrie Snyman se bydrae in die konteks van die Gereformeerde teologie," VE 31(1), Art. \#306, 7 pages DOI: https://doi.org/10.4102/ids.v46i2.58.

8 E.g. Christo J. S. Lombaard, “A comparison and evaluation of four recent works on the interpretation of the Old Testament in South Africa," Scriptura 78 (2013): 467478.

9 Wentzel J. V. van Huyssteen, “Understanding religious texts: The role of models in biblical interpretation," OTE 5 (1987): 9-23; Izak J.J. Spangenberg, "Paradigmaveranderinge in die bybelwetenskappe:'n Bydrae tot die gesprek tussen die bybelwetenskappe en sistematiese teologie," Religie \& Teologie 1/2 (1994): 144-184.

10 E.g. Andries P. Breytenbach, "Departement Ou-Testamentiese Wetenskap" in Ad Destinatum III 1983-1992. ' $n$ Geskiedenis van die Universiteit van Pretoria (eds. Johannes S. Bergh and Ockert, J. O. Ferreira; Pretoria: Universiteit van Pretoria, 1996), 125-127; Andries P. B. Breytenbach and Jurie H. Le Roux, "Old Testament studies," in Ad Destinatum IV 1993-2000. Historical developments and events at the University of Pretoria (ed. Flip van der Watt, Pretoria: University of Pretoria, 2002), 120-122; Jurie Le Roux, "Old Testament Studies: The Story of a Department," VE 30/1 (2009): 1-9; Dirk J. Human, Alphonso Groenewald, Esias E. Meyer, Ananda Geyser-Fouché, Sam S. Ndoga, Gerda De Villiers, "Old Testament studies at the University of Pretoria: Glimpses of the past and Future," in Theology at the University of Pretoria - 100 years (1917-2017): Past, Present and Future. (VE Suppl. 2, 38/4, 2017).

11 E.g. Ferdinand E. Deist, Ervaring, Rede en Metode in Skrifuitleg: 'n Wetenskapsteoretiese ondersoek na Skrifuitleg in die Nederduits Gereformeerde Kerk 1840-1990 (Pretoria: RGN, 1994a); Herrie F. Van Rooy, "Die Bydrae en Relevansie van die Ou-Testamentiese Wetenskapsbeoefening in die Gereformeerde Kerke in Suid- 
11) The OT/Bible in the whole of Africa;

12) Western perspectives' irrelevance to African concerns; ${ }^{12}$

13) Perceived fallacies in contextual African perspectives. ${ }^{13}$

The categories distinguished in (1-13) are admittedly somewhat arbitrary and artificial (hence, a nominalist view of their ontological status will be assumed). Not only do they frequently overlap in the research itself, but the historical overviews in question almost never represent the primary interest of the associated publications cited in the footnotes to each category listed. Perhaps most importantly, the references that do appear in the footnotes are not sufficiently inclusive of all local scholars' historical overviews of South-African Old Testament scholarship, especially in terms of race and gender. Those that do appear are, however, the most visible and therewith a reflection of the ongoing problem of unequal representation even during the post-apartheid era.

\section{B THE RESEARCH GAP AND HOW TO FILL IT}

Various intra- and inter-categorical descriptive and evaluative perspectives are present within the available research on the merits and problems of publications listed in $(1-13)$. Sometimes works assigned to one category are themselves focussed on issues pertaining to discussions in another, e.g. (1) and (2); (6) and (7); (13) and (14), and so on. Despite the contributions that such overviews have made to our understanding of the relevant topics, one gap that still exists is constituted by the lack of any research aimed at the clarification of constructions of the concept of philosophy in "Western" 14 historical overviews of local OT

Afrika (1869-1994)," In die Skriflig 29/1 (1995): 47-76; Marius Nel, "Pentecostals' reading of the Old Testament," VE 28/2 (2007): 524-541.

12 E.g. Madipoane Masenya (ngwa'na Mphahele) and Hulisani Ramantswana, "Anything new under the sun of South African Old Testament scholarship? African Qoheleth's review of OTE 1994-2010." OTE 25/3 (2012): 598-637; “Anything new under the sun of African biblical hermeneutics in South African Old Testament scholarship? Incarnation, death and resurrection of the Word in Africa." VE 36/1 (2015): 7 pages.

13 E.g. Christo J. S. Lombaard, "The relevance of Old Testament science in / for Africa: two false pieties and focussed scholarship." OTE 19/1 (2006):144-155; Esias E. Meyer, "South African Old Testament criticism: Squeezed between an ancient text and contemporary contexts." HTS 71/3 (2015): 1-7.

14 Not understood in any essentialist manner. Though therefore not focussed on the "African" perspectives (to the extent that the distinction "Western"/"African" is warranted or practical, this study can be seen as providing the previously marginalised views (or others, such as feminist perspectives) with raw data that can be used as part of their own critiques of the constructions of the concept of philosophy in "Western" or "traditional" perspectives. Examples of such "African" perspectives themselves explicitly using the terms "philosophy"/"philosophical" include those mentioned in (12) above, that is, Masenya and Ramatswana whose "Anything new under the sun of South African Old Testament scholarship?" and "Anything new under the sun of 
scholarship in (roughly speaking) the post-apartheid era. Due to ambiguous relations between OT studies and philosophy during the latter half of the $20^{\text {th }}$ century, ${ }^{15}$ even where philosophy has been most visible and tolerated (such as OT hermeneutics and reflections on methodology), ${ }^{16}$ the particular philosophical disciplines, problems, perspectives, thinkers and eras privileged within local histories of South African OT scholarship specifically have, to date, not been systematically and holistically scrutinised. ${ }^{17}$ Though prima facie perhaps negligible, the nature and scope of philosophical frameworks operative during the time will show the topic to be relevant as prolegomenon to all discussions of the future of the academic discipline in the country.

The methodology opted for in the present article is basic "metaphilosophical commentary" which, in the present context, equates to a thirdorder analysis of second-order philosophical concepts, concerns and categories as are implicit in the verbatim use of words "philosophy" and "philosophical". ${ }^{18}$

African biblical hermeneutics in South African Old Testament scholarship?" contains references to various related meta-philosophical configurations, e.g. "Western frameworks and philosophies," "African epistemologies, philosophies and frameworks," "African philosophies, frameworks and the experiences of the struggles of African peoples," "the (critical) philosophy of Black Consciousness," "existentialism, a Western philosophy," "African wisdom and philosophy" and "philosophies and academic debates".

15 James Barr, The Concept of Biblical Theology. An Old Testament Perspective (Philadelphia: Fortress Press, 1999), 146-171; and History and Ideology in the Old Testament: Biblical Studies at the End of a Millennium (Oxford: Oxford University Press), 10; cf. also as historical-philosophical backdrop Jonathan Sheehan, The Enlightenment Bible: Translation, Scholarship, Culture (Princeton: Princeton University Press. 2005) and Steven D. Moore, and Yvonne Sherwood, The Invention of the Biblical Scholar. A Critical Manifesto (Syracuse: Syracuse University Press, 2008). 16 See, e.g., Jaco Gericke, The Hebrew Bible and philosophy of religion (Resources in Biblical Literature 70; Atlanta: Society of Biblical Literature, 2012), and What is a God: Philosophical Perspectives on Divine Essence in the Hebrew Bible (London: Bloomsbury T \& T Clark, 2017).

17 The concept of meta-philosophy is, however, essentially contested. See classically Morris Lazerowitz, “A Note on 'Metaphilosophy'," Metaphilosophy 1/1 (1970): 91-91 (sic); Giles Deleuze and Félix Guattari, What is Philosophy? (trans. Graham Birchill and Hugh Tomlinson, London and New York: Verso, 1994), Timothy Williamson, The Philosophy of Philosophy (Malden MA/Oxford: Blackwell, 2007). For a recent overview in English, see Nicholas Joll, "Contemporary metaphilosophy," The Internet Encyclopedia of Philosophy, n.p. [cited on 2 February 2018]. Online: http://www.iep.utm.edu/.

18 The focus on the mere use of the word "philosophy" and derivatives (e.g. "philosophical") might be seen as oversimplifying matters. This is done, however, in the tradition of Wittgenstein and ordinary language philosophy to the extent that elements of such an approach remain viable even if the larger theoretical framework has been justifiably criticised. As such the approach should not be confused with an 
The publications under investigation and wherein these words appear are limited to historical overviews of the kind discerned in $(1-5)$ within the typology constructed above with publication dates between the years 1993 and 2017. ${ }^{19}$

\section{C "PHILOSOPHY" IN HISTORICAL OVERVIEWS}

The 1993 publication, A Story of Two Ways by Jurie Le Roux, is perhaps the most extensive inquiry into the particular type of local Western historical overviews of South Africa OT scholarship under consideration, i.e. a full monograph, as opposed to simply, as in most cases, limited to the confines of a journal article (or sub-section thereof). Covering the period from 1957 (when the OTSSA was founded) to 1987, a substantial number of references to philosophy can be found, mostly in the context of discussions of the work of Ferdinand Deist. The latter is rightly noted as having been one of the greatest single influences on OT scholars' constructions of philosophy and the philosophical in the era under consideration (and no doubt, to a large extent, thereafter as well).

The first reference to "philosophy"/"philosophical" in Le Roux's historical overview is found the words "the philosophy underlying a method", the latter within the larger context of a section on OT hermeneutics (sometimes reduced to "rules for exegesis"). ${ }^{20}$ In contrast, "philosophical considerations" have become more prominent than ever since Deist emphasised the need for a "science of theory." 21 The location of the philosophical is specified as "rooted in a worldview" which, in turn, operates on the level of "philosophical assumptions" themselves "underlying a particular approach." 22 The effect of "current philosophy" on methodology is, furthermore, suggested as being so pervasive that even seemingly incommensurable ways of reading ("historical criticism and structuralism") actually share a similar "philosophical framework", that is a "positivistic philosophy". ${ }^{23}$ These and other of Deist's critiques of local scholarship are constructed as the product of developments in "the philosophy of history" since the "Aufklärung". 24

attempt to draw general and/or normative conclusions about the meaning and significance of the concept based on quantity and location. Though a larger study should not be so limited, the confines of a journal article were deemed sufficient reason to limit the discussion to the philosophical assumptions evident in the verbatim use of the term "philosophy" itself.

19 Other examples of related research where the words "philosophy"/"philosophical" also appear (sometimes only once or twice and in a way similar to the work under consideration) will included in the footnotes to the particular paragraph.

20 Le Roux, Story of Two Ways, 35.

21 Le Roux, Story of Two Ways, 36.

22 Le Roux, Story of Two Ways, 38.

23 Le Roux, Story of Two Ways, 38-39.

24 Le Roux, Story of Two Ways, 39. The latter German term for the "Enlightenment" era is preferred, partly given the era's Western scholars' connections with German 
Many (even other local OT scholars) considered this type of "philosophical interest" problematic. This was in itself revealing of the "role of philosophy" in how history and historical inquiry were understood. ${ }^{25}$ The "philosophical implications" of modern philosophers as diverse as "Kant, Herder, Hegel, Dilthey and Popper" are noted as among the names mentioned of those who contributed to the invention of new concerns as to how knowledge in relation to historical approaches to literatures should be represented. ${ }^{26}$ The decisive role played by the associated philosophical considerations meant that "past and contemporary philosophers and their philosophies" could no longer be ignored (thereby presupposing they were). ${ }^{27}$

When we encounter the next reference to "philosophy" in Le Roux's overview we find ourselves in the context of a discussion of the contributions of Septuagint expert Johann Cook. Cook's research dealt with the question of the nature and extent to which Plato's "philosophical ideas" are present in Genesis 1-2 LXX, even though Hellenistic Judaism had ambivalent "relations with philosophy", mostly involving it to restate theological views in "philosophical terms." 28

A further relevant bit of content appears when Le Roux takes us back to the days of local English Anglican Bishop John William Colenso's contributions to the local study of the Pentateuch. The discussion addresses the need for "a philosophical framework" which is seen as being existentially and polemically useful for reconciling the scientific spirit with a believing heart. In the case of Colenso himself, the "underlying philosophy" (identified as the "British variety of idealism" of the type promoted by Samuel Taylor Coleridge) made it possible to be both a critical scholar of the Pentateuch and a devout Christian missionary. ${ }^{29}$ Subsequently, the "philosophy" of a more liberal hermeneutical context (among Afrikaners during the first half of the twentieth century) allowed Johannes du Plessis to accept the findings of historical critical exegesis as well, as whilst hoping to retain his membership in the Dutch Reformed Church. ${ }^{30}$

In the next round of discussing the contributions of Deist with reference to a different area of OT scholarship (Deist was a remarkable "all-rounder", no least for being a Semitic language specialist), Le Roux states that he (i.e. Deist) did not wish to "corrupt sound exegesis with philosophy". Again it is noted, in relation to the motive just mentioned, that Deist was not overly dependent on

colleagues, as was the case with Deist who became acquainted with "the philosophy and theory of science" during his research in Marburg with Otto Kaiser.

25 Le Roux, Story of Two Ways, 58.

26 Le Roux, Story of Two Ways, 58-59.

27 Le Roux, Story of Two Ways, 59.

28 Le Roux, Story of Two Ways, 85.

29 Le Roux, Story of Two Ways, 104.

30 Le Roux, Story of Two Ways, 107. 
only "one philosopher", 31 yet always interested in the "underlying philosophy" of interpretative approaches. The particular example chosen for philosophical criticism is "Traditionsgeschichte" as a means to date prophetic oracles. ${ }^{32}$ More specifically, "philosophical idealism" of the kind found in Hegel's "philosophy of history" is identified as problematic as auxiliary "philosophy" or "theory of science." 33 The particular section concludes with a doubling back via a reference to Deist's emphasis on the importance of "the philosophy or the theory of science" for appreciating the "intellectual" context of Pentateuch scholarship as it intermingles with otherwise apologetic/pastoral concerns. ${ }^{34}$ In an alternative wording of the same idea, Le Roux later notes how the "philosophy of science" influenced Deist's hermeneutical reflection on recent developments in research on the prophetic literature in the OT. ${ }^{35}$

With reference to other of the OT's poetic texts, the words "Cartesian philosophical assumptions" are found in the context of a summary of Jasper Burden's critique of Wilfred Watson's reception of Robert Lowth on the idea of parallelism. In contrast, a more useful "philosophical grounding", according to Burden as read by Le Roux, was to be in a more scientific context, specifically Einstein's theory of relativity in the sense of "approximating the balance of mental experience by linguistic structures in literature". ${ }^{36}$

Finally, Le Roux mentions the fact that Jimmy Loader referred to the "wisdom teachers" of the OT as "philosophers" given their (scientific) interest in rational reflection on empirical observations of the "cosmic order", all within the quest for a "unified" theory of the world.$^{37}$ The sages of Loader are also called "practical philosophers" given the optimistic moral epistemology underlying their interest in determining right and wrong actions in everyday life-contexts. ${ }^{38}$ These "ancient philosophers" suggested that wise actions acknowledging divine providence led to prosperity. ${ }^{39}$ In a similar vein, "wisdom and philosophy" are linked in the work of Philip Nel's interpretation of the concept of "the fear of the Lord", the latter seen as harmonising the "reason/philosophy and revelation" dichotomy. ${ }^{40}$ Last but not least, Le Roux mentions how Martin van Niekerk wrote of Qohelet as "a philosopher" in light of the latter's Carpe Diem ethic. ${ }^{41}$

\footnotetext{
31 See above, footnote 27, and here Le Roux, Story of Two Ways, 136.

32 Le Roux, Story of Two Ways, 147.

33 Le Roux, Story of Two Ways, 148.

34 Le Roux, Story of Two Ways, 157.

35 Le Roux, Story of Two Ways, 250.

36 Le Roux, Story of Two Ways, 275.

37 Le Roux, Story of Two Ways, 306.

38 Le Roux, Story of Two Ways, 306.

39 Le Roux, Story of Two Ways, 306.

40 Le Roux, Story of Two Ways, 307.

41 Le Roux, Story of Two Ways, 308.
} 
As noted, Le Roux's Story is the most extensive example of traditional historical overviews featuring the words "philosophy"/"philosophical" in a manner of immediate and direct relevance to the focus of the present study. Though evolving in his personal philosophical perspectives, assimilating rather than replacing the earlier (existential and romanticist) views with those of French post-structuralist philosophers such Michel Foucault and Jacques Derrida, as well as the hermeneutics of Gadamer, subsequent historical overviews of local research on the OT by Le Roux frequently re-emphasised the same points as those discussed here regarding the specific nature and function of philosophy in earlier scholarship. ${ }^{42}$

The second relevant historical overview - ironically entitled South African Old Testament Studies and the Future is that by Ferdinand Deist himself. In his contribution to a collection of articles on local OT scholarship in the particular edition of Old Testament Essays (volume 4 of the $7^{\text {th }}$ edition in 1994), Deist includes as category of research with reference to which local scholars have reflected on called "philosophical and hermeneutical assumptions". ${ }^{43}$ Under the rubric are subsumed his own "Ope Vrae aan die Diskoersanalise" (1978), "Gedagtes oor die Aard en Moraliteit van Wetenskaplike Kennis" (1979), "Relatiwisme en Absolutisme: Kan dit oorkom word? Oor 'Bybelse' en 'Dogmatiese' Teologie" (1988) and "Old Testament and Modern Historiography: On Presuppositions and Hermeneutics" (1990). ${ }^{44}$ Others are Hendrik Bosman's "Modelle van Skrifuitieg: Samehang en verskil" (1986) and "Wetenskapsteorie en inleidingswetenskap" (1987), Piet Boshoff's "Eksistensiale verstaan van die Ou Testament: Die Teologiese Arbeid van Antonius HJ Gunneweg" (1987), Jimmy Loader's "Interpreting the Old Testament in South Africa - Exegesis, Existential Meaning and Social Relevance" (1987), Willie van Heerden's "Die Interpretasie van die Boek Jona in die Nederduitse Gereformeerde Kerk: 'n Hermeneutiese Studie" (1988) and

42 See e.g. Le Roux's numerous online references to philosophy on the University of Pretoria's telematics education site: teo.co.za. See also his "Pro Pent: A Project for the Study of the Pentateuch in South Africa," HTS 68/1 (2012): art 1277, 10 pages DOI: https://doi.org/10.4102/hts.v68i1.1277. Le Roux returns to Colenso and Du Plessis, both noted as needing a "theological or philosophical framework" to enable these scholars to be critical and scientific while remaining good believers at the same time. This "philosophical framework" is said to be typical of OT scholarship in South Africa. 43 Deist, South African Old Testament Studies and the Future, 35.

44 Deist, South African Old Testament Studies and the Future, 35. Understandably, his “Ervaring, Rede en Metode in Skrifuitleg: 'n Wetenskapsteoretiese Ondersoek na Skrifuitleg in die Nederduits Gereformeerde Kerk 1840-1990 (also published in 1994) included in the bibliography is not mentioned. 
Marius Swanepoel's “Wetenskapsteorie, Eksegetiese Metodologie en Ou Testament Teologie" (1990). ${ }^{45}$

The next example of a historical overview in which the general terms "philosophy"/"philosophical" appear is an article written by Herrie Van Rooy. ${ }^{46}$ He tells the story of how "philosophy" was one of the disciplines students had to master in training for the ministry at the theological school at Burgersdorp. ${ }^{47}$ This was, however, only on the level of an undergraduate subject and highly conservative and Calvinist constructed (i.e. as apologetics and worldview studies). It was also located as it was within the A section of disciplines in the curriculum (along with Hebrew, Greek and Latin), as opposed to those in the Bsection, namely Biblical History, Biblical Geography, Jewish Antiquities and the Foundations of Biblical Interpretation. Van Rooy observes the way in which "philosophy and hermeneutics" were usually linked to parallel the practice of the Reformed Churches' approach at Kampen in the Netherlands. The OT hermeneutics in which Reformed scholars were initially trained during the narrated time was thus mainly interested in "the philosophical foundations" "underlying" various "exegetical methods" and as analysed via "theoretical investigation" (still, again opposed to the caricature of it only being interested in "rules for exegesis"). ${ }^{48}$

Other initially Reformed ("Gereformeerde") OT scholars also conducted research that included historical overviews in which philosophical concerns featured prominently. Hans Van Deventer thus enters into dialogue with the conjunction of philosophy and hermeneutics as noted by van Rooy by constructing the concept under consideration in the form of the "philosophical foundations" hotly debated in discussions of OT interpretation during the 1970s and 1980s. ${ }^{49}$ The interlocutors - called OT "scientists" representative of the associated discussions within the three Reformed traditions include Francois N. Lion-Cachet in dialogue with Ferdinand Deist during 1984, as well as Gerrie Snyman and Wim Vergeer (NT) during 1992-1993. Van Deventer also follows Deist in his reference to the "philosophical tradition" of

45 Deist, South African Old Testament Studies and the Future, 35. Unfortunately these important works, all of which also feature sections of historical overviews with references to philosophy, cannot be discussed here as the time of publication fall outside the scope of the present inquiry.

46 Herrie van Rooy, "Die Bydrae en Relevansie van die Ou-Testamentiese Wetenskapsbeoefening in die Gereformeerde Kerke in Suid-Afrika (1869-1994)," In die Skriflig 29/1 (1995): 47-76.

47 Van Rooy, "Bydrae en Relevansie,"58.

48 Van Rooy, "Bydrae en Relevansie," 58.

49 Hans J. M. van Deventer, "Verband tussen die Ontwikkelinge in Filosofiese Hermenetiek en Ontwikkelinge in Benaderings tot Bybelinterpretasie," Koers 64/1 (1999): 393-413.

50 Van Deventer, "'Verband tussen die Ontwikkelinge" 405. 
"common sense realism" that lay covert and coiled at the heart of what was promoted as "historical-literal" (usually neither of the two) interpretations of the OT. ${ }^{51}$

In a historical overview of local research, Christo Lombaard uses the terms "theological or philosophical framework" in the tradition of Le Roux where these are taken to serve as an apology for a critical approach to the Pentateuch and aimed at placating concerns of it being a recipe for the loss of faith. ${ }^{52}$ Lombaard shrewdly observes that one of the primary motives of Deist's near obsession with "philosophical hermeneutics" (in the sense of "what it means to understand") was not so much a personal interest in philosophy for its own sake, but for the most part a necessary complication of meta-theoretical discourse in order "to waylay fears and criticisms of his historically oriented views" from the Church authorities. ${ }^{53}$ Elsewhere, ${ }^{54}$ Lombaard writes of the "underlying philosophical reasons" behind Deist's critique of local OT exegesis, which initially appealed mostly to insights from the "philosophy of history" "philosophical components of reality", constructed as the "truths" acceptable within particular church and, as identified by Thomas Kuhn and others, also scientific communities. ${ }^{56}$ Lombaard also mentions his own "lingering philosophical doubts" about Louis Jonker's proposed "interactional approach" and concerning Gerald West's "European philosophical hermeneutics" in the service of liberation, black and feminist theologies. ${ }^{57}$ Yet Lombaard ultimately also concedes that all views (including those of Le Roux's and even his own) cannot but try to base itself on "solid philosophical presuppositions", whether explicit (Deist) or implicit (e.g. in Le Roux's "philosophical grounding" and West and Jonker's "philosophical undercurrents"). ${ }^{58}$

Another influential and related historical overview comes from Louis Jonker who similarly conjoins "philosophical and hermeneutical understanding"

51 Van Deventer, "Verband tussen die Ontwikkelinge," 405.

52 See Christo Lombaard, "Of Serpents, Reeds, Understanding, and Turns. Some Perspectives on Implied Apologetics and Pentateuch Theory," Studia Historiae Ecclesiasticae XXXIII/1 (2007): 351-365.

53 Lombaard, "Of Serpents, reeds, understanding, and turns," 354.

54 See Christo Lombaard, "Four recent works on the interpretation of the Old Testament in South Africa, with evaluation and some implications," Scriptura 78 (2013): 467-478.

55 See Ferdinand E. Deist, Historiese heuristiek, teologiese hermeneutiek en Skrifgesag (Port Elizabeth: Universiteit van Port Elizabeth (Navorsingspublikasie C 11. 1979).

56 Lombaard, "Four recent works," 469.

57 Lombaard, "Four recent works," 470.

58 Lombaard, "Four recent works," 473. 
with reference to the idea of "authorial intention since the Enlightenment". 59 The primary source is the work of Bosman who in 1992 wrote an influential piece on authorial intention and historical-critical interpretation as a contribution to a Festschrift to Deist entitled "Old Testament Science and Reality." Jonker also mentions Le Roux's "general philosophical reflection" on "the historical" in OT scholarship in the tradition of Gabler's distinction between dogmatic and biblical theology. ${ }^{60}$ More specifically, concurring with Le Roux as noted earlier, "philosophy and theology" combine to determine how both the concepts of history and the theory that inform the method concerned with the historical interpretation of the text are constructed. In this case, however, the research of Le Roux which Jonker is in dialogue with his publications entitled "The Nature of Historical Understanding (or: Hermeneutics and History)" and "Israel's Past and the Feeling of Loss (or: Deconstructing the 'Minimum' of the 'Minimalists' even further". 61

This section involving the identification of the uses of the words "philosophy" and "philosophical" in historical overviews since Le Roux's (1993) story concludes here. Indeed, several more recent local historical overviews of South African OT scholarship also containing the words "philosophy"/"philosophical" are available. ${ }^{62}$ However, their foci fall outside the scope of the present article (as limited to the genres of a-e in the initial typology constructed) and for this reason are not discussed here.

59 Louis C. Jonker, "Why history matters: The place of historical consciousness in a multidimensional approach towards biblical interpretation," VE 34/2 (2013), 3. DOI: https://doi.org/10.4102/ve.v33il.714

60 Jonker, "Why history matters, 4.

61 Jonker, "Why history matters, 5, n. 15.

62 See also as supplement to Le Roux's Story, see Bosman, “Ants, Spiders or Bees . . . and Ticks?" 636-654. The references to philosophy occur in the context of a discussion of the contribution of Jaco Gericke who is said to read the OT "from a Philosophy of Religion Perspective" The case for "Philosophical views on Yahwism" is moreover held to be warranted by recent trends in biblical theology allowing for a more nuanced "involvement of philosophy for the understanding of the Old Testament" than was the case during most of the $20^{\text {th }}$-century. Gericke's work is also mentioned in references to philosophy in the historical overview of Masenya and Ramantswana, “African Qoheleth's review of OTE 1994-2010," 598-637. Another historical overview referring to philosophy, albeit only briefly, is found in Human et al., "Old Testament Studies at the University of Pretoria" Here the references are to "philosophical concepts" from postmodern literary theories as present in the research of Ananda Geyser-Fouché. In the context of the above-mentioned publication, this is the only reference to philosophy and further linked to the critique of ideology. 


\section{SOME META-PHILOSOPHICAL REMARKS}

Prima facie and on second thought, the precise and possibly primary metaphilosophical location and background presupposed in appearances of the words "philosophy" and "philosophical" in the historical overviews under consideration are not that easy to pin down. One reason for this is the fact that local and so-called Western "liberal" OT scholars constructing the concept of philosophy in their writing of historical overviews have been more informed (wittingly or not), by the so-called Continental (as opposed to analytic or pragmatic) traditions in philosophy (though this is still on the individual level at times a generalisation). Once this is taken into consideration, it becomes easier to account for and bring together the inordinate array of philosophical presuppositions, problems, perspectives and persons involved.

First of all, one should ask the question as to the location of the philosophical in local OT scholarship according to the selected historical overviews published between the years 1993 and 2017. Here, various distinct and often overlapping conceptual coordinates are given. For example, the philosophical is said to be present in the "assumptions", "foundations", "frameworks", "ideas" and "traditions" of OT scholars. They "underlie" and "root" exegetical "methods" and/or "models". ${ }^{63}$ Yet in themselves, they are said to be part of even more foundational "worldviews", "paradigms", "historical eras", and even "theological curricula". Their operations involve "determining", "legitimating" and "influencing" a particular interpretative approach, so that one develops "philosophical dependence" and "philosophical interests", irrespective of whether this is construed positively or negatively.

From the oft-used conjunctive expression "philosophical and hermeneutic(al)" assumptions/ frameworks ${ }^{64}$, it might prima facie seem that the

63 See already an anticipation of the basic idea in Philip J. Nel, "A critical Perspective on Old Testament exegetical methodology," OTE 2/3 (1989): 64-74.

64 Though the terminology is shared by "African" perspectives, the latter have managed to move beyond the over-dependence on the philosophy of science and can be meta-philosophically more aptly located within the neglected context of African philosophy. For example, in one of a recent series of publications, Masenya \& Ramantswana, "African Qoheleth's Review of OTE 1994-2010," OTE 25/3 (2012): 598-637 refer to "Western frameworks and philosophies" which are seen as what Africans were made to accept and indoctrinated with on a large scale. They also mention "African epistemologies, philosophies and frameworks" allowing African OT scholars to provide grassroots communities with a positive impact, further expanded to become the lens of "African philosophies, frameworks and the experiences of the struggles of African peoples", ultimately inspired by "the (critical) philosophy of Black Consciousness." See also Masenya \& Ramatswana's "Incarnation, Death and Resurrection of the Word in Africa," 1-7. Doi: https://doi.org/10.4102/ve.v36i1.1353. The authors criticize Le Roux's continued endorsement of "existentialism, a Western philosophy" and offer "African wisdom and philosophy" as more relevant to life in the 
primary intra-disciplinary context where the philosophical is assumed to reside is OT hermeneutics. Of course, what these involved is diverse as is evident from differences in the kinds of philosophy and hermeneutics various OT scholars identify with and their assumed relationship to OT exegesis. Associated wordpairs also attested include "philosophical and epistemological" or "philosophical and theological". Add to that references to the philosophical "assumptions/frameworks" that "underlie a theory", and the primary supervening philosophical discipline turns out to be something other than what is popularly assumed to be the case.

While it cannot be denied that the intra-disciplinary location of the philosophical in OT studies itself is OT hermeneutics, it does not follow that philosophical hermeneutics is the primary cross-disciplinary informant. Neither can one say that it is the philosophy of history or even epistemology per se, although these are also among the most popular philosophical domains of discourse. Rather, it is "the philosophy of science."

To appreciate the extent to which presuppositions, problems, perspectives typically at home in the "philosophy of science" dominate trends in crossdisciplinary references and allusions in historical overviews of local OT scholarship, one needs to look beyond references to the reason for dropping names such as Dilthey, Popper, Kuhn, Feyerabend and others. The depth of dependence in local meta-philosophical assumptions on the framework offered by this field extends all the way down to the most basic technical theoretical jargon and all the way up to the most fashionable trends in systematic theology's interest in the relationship between science and religion.

One also needs to consider the variations involved in the historical overviews' references to "theory" in the associated philosophical discussions. To be sure, "theory" can be seen as "literary theory", yet even here it would seem that what is being sought is, as explicitly noted, "a science of theory" ${ }^{65}$ This is evidenced by one of most popular choices for the field of OT scholarship itself, namely as "OT science." ${ }^{\prime 6}$ Hence the repeated emphasis on "scientific standards"

context of Modern issues. They also refer several times to "philosophies and academic debates" which are seen as unwarranted sources of comfort out of place in contemporary in readerly contexts.

65 On which, see Hendrik L. Bosman, "The historical understanding of the Old Testament in South Africa: Colenso, Le Roux and Beyond.” VE 34/2 (2013) Art. \#793. DOI: https://doi.org/10.4102/ve.v34i2.793.

66 Aside from the numerous references to "Old Testament science" and "Ou Testamentiese Wetenskap" (cf. European (German) "Bibelwissenschaft") in the content of related research itself, they are also prominent already in the titles of associated literature, e.g. in the bibliography of this study alone we see it in the following entries: Hendrik L. Bosman, "Wetenskapsteorie en inleidingswetenskap," Skrif en Kerk 8/2 (1987): 127-141; Andries P.B. Breytenbach, "Departement Ou-Testamentiese 
found in wording the values of both the Old Testament Society of South Africa and its official journal Old Testament Essays. No further elaboration on what exactly these standards are supposed to be is provided; it is taken for granted that enough is implicit in the criteria provided for authors and reviewers of articles to get the basic idea. ${ }^{67}$

That being said, an ambivalent attitude towards science is also implicit in the same privileging of the philosophy (or theory) of science. There is a reason why particular philosophers are most noted, namely Kant, Hegel, Herder, Coleridge, Nietzsche, Dilthey, Popper, Feyerabend, Kuhn and others. They are enlisted to show that scientific truths are relative and that theology in general and OT interpretation in particular have as good a reason as any for being part of intellectual discussions. ${ }^{68}$ So while the European "Enlightenment" is heralded

Wetenskap.” Ad Destinatum III 1983-1992. 'n Geskiedenis van die Universiteit van Pretoria (eds. Johannes S. Bergh and Ockert, J. O. Ferreira. Pretoria: Universiteit van Pretoria, 1996), 125-127; Ferdinand E. Deist, "Gedagtes oor die aard en moraliteit van wetenskaplike kennis." Theologia Evangelica 12/2 (1979b): 16-21; "Naiewe realisme en Ou-Testamentiese wetenskap in die Nederduitse Gereformeerde Kerk" in In mensetaal oor God se Woord (eds. Willem S. Prinsloo \& Wil Vosloo; Cape Town: Lux Verbi, 1988), 23-32; Ervaring, rede en metode in Skrifuitleg: 'n Wetenskapsteoretiese ondersoek na Skrifuitleg in die Nederduits Gereformeerde Kerk 1840-1990 (Pretoria: RGN, 1994b); Hennie W. Rossouw, Wetenskap, interpretasie, wysheid (Port Elizabeth: Universiteit van Port Elizabeth, 1980); Izak J. J. Spangenberg, "Paradigmaveranderinge in die bybelwetenskappe:'n Bydrae tot die gesprek tussen die bybelwetenskappe en sistematiese teologie," Religie \& Teologie 1/2 (1994): 144-184; Marius G. Swanepoel, "Wetenskapsteorie, eksegetiese metodologie en Ou Testament teologie." HTS 46/1 (1990): 190-206; Wentzel J.V. van Huyssteen, "Understanding religious texts: The role of models in biblical interpretation." OTE 5 (1987): 9-23; and "Truth and commitment in theology and science: An appraisal of Wolfhart Pannenberg's perspective," HTS 45 (1989): 99-116. Herrie F. van Rooy, "Die bydrae en relevansie van die OuTestamentiese wetenskapsbeoefening in die Gereformeerde Kerke in Suid-Afrika (1869-1994)," In die Skriflig 29/1 (1995): 47-76; Christo J.S. Lombaard, "The relevance of Old Testament science in / for Africa: two false pieties and focussed scholarship." OTE 19/1 (2006): 144-155.

67 See http://otwsa-otssa.org.za/ote/index.php/journal.

68 Related warranted concerns have been voiced by the African scholars mentioned in this study, albeit from the perspective of African philosophy and in the context of the political turn in cultural studies. The findings of this article hope to supplement the implied relativizing of traditional Western approaches to narrating the story of how we got here, hermeneutically and philosophically (and what challenges lie ahead). The mixed obsessions with the philosophy of science have allowed the more obviously fundamental and relevant issues, not only in politics (where to some extent this has become an obsession without being really dealt with), but also in philosophy of religion/philosophical theology from which this interest is borrowed to be bracketed. Though partly explained by anti-philosophical sentiment in the discipline of OT studies 
for its turn to reason, it is even more celebrated as the beginning of critical reflection on the limits of reason. Hence Kant rather than Descartes (or any other philosophers of the time, for that matter) is the epistemological hero in many local historical overviews. ${ }^{69}$

The cognitive tension resulting from this ambivalence partly accounts for the choice of ontological perspective within the philosophy of science most frequently adopted. Almost without fail, the historical overviews appear to endorse some form of "critical realism". The latter itself is frequently taken to represent the golden mean betwixt and between "naïve/common sense realism" (often conflated with "positivism") and anti-/non-realism (more often called "instrumentalism", "relativism", etc.) Naïve realism is nevertheless sometimes still operative in meta-theory and meta-language as regards the ontological status of "language" (e.g. metaphors) as "texts" (e.g. the OT), "philosophical eras" (e.g. the Enlightenment), "religious objects" (e.g. God), "theories/methods" (e.g. structuralism/historical criticism), disciplines ("philosophy of science", "positivism").

While this particular choice of self-identification can be partly accounted for to show that faith and reason can be "friends with benefits", another decisive factor is the academic requirement to show itself as intellectually respectable to the extent of being worthy to be hosted within an institution of higher education. And what better way to do so than by using the philosophy of science to both construct OT scholarship as really scientific in one sense or another, while at the same time relativizing the scientific enterprise itself lest biblical interpretation be judged as having only pseudo-scientific status? This explains why the references to philosophy in the historical overviews frequently appear not only as part of rejections of anti-scientific religious fundamentalism on the one hand, but objectivism, positivism, and the kind of realism frequently encountered in

well known, this is itself shown to be inconsistent given all the philosophical reflection already noted.

69 Besides the views already discussed, another good example of this trend is found in the historical overview of Alphonso Groenewald, "Once again methods: Is there a method in the madness?" OTE 17(4) (2004): 544-559. DOI: https://doi.org/10.4102/hts.v63i3.231. Groenewald follows Deist and Le Roux when he refers to "philosophers of the Enlightenment" (Aufklärung) in general to Immanuel Kant in particular. The latter is called its "greatest and most influential philosopher," forever changing the way we think about "the science of exegesis" and contributing to the development of the historical-critical "method". The insights of the Enlightenment are noted as not having reached grassroots level because, as Le Roux always notes, in South Africa "we missed it". As for Kant, what is emphasised is the epistemological implications of his metaphysical insights on the interplay of subject/object and essence/appearance relations. 
contemporary secularism and atheism on the other. In this manner, the often opposing demands of University and Church can be satisfied ${ }^{70}$

Other interdisciplinary parties, however, also demand allegiance. While Gabler's distinction of and suggestions for the separation of dogmatic and biblical theology (and Bauer for OT and NT studies) are noted within historical overviews as a significant event, the turn to (the philosophy of) science as evidence in the same discussions has not, and perhaps cannot, in practice, be maintained. To be sure, the concerns of the older "orthodox" varieties of dogmatics (and NT studies) no longer supervened so intrusively on mainstream local OT hermeneutics. Yet, more "critical" or "liberal" varieties still did, which is why OT scholars had to reduce their hermeneutics and other theoretical reflection to positioning themselves within the religious/science debates. Hence the popularity at the time of, inter alia, Pannenberg, van Huyssteen, ${ }^{71}$ the "Dutch ethical theologians"72, New Testament scholars (Bultmann, Vorster and Lategan $^{73}$ et al.)

The systematic-theological determination of the ways in which local overviews of the history of South African OT scholarship constructed the concept of philosophy was decisive. The samples discussed, insofar as they seek to view the OT in a historically-conscious manner, frequently assume anachronistic views in philosophy of religion, i.e. that the nature of religious language is metaphorical, that religious epistemology anti-evidentialist (or postfoundationalist). Clearly the strained relations between mythos and logos, religion and philosophy, faith and reason, theology and science, church and academia, belief and scholarship were never really overcome, even in postfundamentalist Christian spirituality.

The epistemological assumptions of the majority of historical overviews discussed can therefore be located within weak and constructive forms of postmodernism. In order to do so, however, they had to adopt what Richard Rorty

70 See the relevant parts of the discussion in Rian Venter, "Theology and the (post-) apartheid university: Mapping discourses, interrogating transformation," Transformation in Higher Education 1/1 (2016): 1-6.

71 Van Huyssteen, "Understanding religious texts," 9-23; and "Truth and commitment in theology and science," 99-116. See also the related and influential works of local philosophers such as, amongst others, Rossouw, Wetenskap, Interpretasie, Wysheid.

72 See e.g. Johannes H. Vorster, "Exploring similarities between the German and the Dutch ethical traditions: Possibilities of the history of religion for a theological approach to Old Testament studies in South Africa," HTS 66/1 (2010), Art. \#428, 12 pages. DOI: https://doi.org/10.4102/hts.v66i1.428.

73 Bernard C. Lategan and Willem S. Vorster, Text and reality: aspects of reference in biblical texts. (Philadelphia: Scholars Press. SBL Semeia Studies, 1985). 
showed can be seen as two mutually exclusive intellectual agendas. ${ }^{74}$ The one agenda can be traced back to Kant and back to the future through the neoKantian tradition from Marburg that significantly influenced historical overviews in the Deistian tradition. The other began with Hegel and can be linked to some of the more historicist and post-structuralist of the later Le Roux and those influenced by him. ${ }^{75}$

The conundrum is as follows: In Kantian philosophy, a primary concern is the relationship between representations and what is represented, whereas from Hegelian perspectives the question of our scholarly representations' relation to non-representations does not arise. ${ }^{76}$ In the latter context there are no representations of things, the only thing one can coherently talk about is a given re-interpretation of prior re-interpretations and so on ad infinitum, i.e. no research problem is concerned with something "out there" in the text, but simply with how the various scholarly ideas about previous scholarly ideas can be related. ${ }^{77}$ Local histories of interpretation attempt to do justice to both these views and therefore contain an inherent tension between a Kantian tradition in the philosophy of science (were theories are seen as imperfect perspectives on the facts) and a Hegelian one (where theories are seen as scholarly artefacts currently popular and forever in need of alteration for reasons other than the "facts"). ${ }^{78}$

The Kantian tradition in local historical overviews implies that the best OT scholarship comes in scientific form, with the necessary terms and conditions of course. The Hegelian trend, by contrast, suggests that that the scientific enterprise is a cultural sector, which would then include OT science, yet the worries of which only makes sense when viewed historically. This explains why OT scholars are constructed in these overviews both as straightforward, downto-earth, scientists hoping to "get things right" and as rebels and believers who are justified in being such in light of certain philosophical problems regarding the ontological status of scientific methods and theories within the modern episteme. $^{79}$

Other examples of the same tension are clearly evident. On the one hand, the impression given is that where we are now in the history of OT interpretation is the outcome of "purifying" epistemic transformations, affording us and the public increasingly clearer views of solutions to persistent research problems. ${ }^{80}$

74 See Richard Rorty, "Philosophy as a Kind of Writing: An Essay on Derrida," New Literary History 10/1 (1978): 141-160.

75 Cf. Rorty, "Philosophy as a Kind of Writing, 142.

76 Cf. Rorty, "Philosophy as a Kind of Writing, 143.

77 Cf. Rorty, "Philosophy as a Kind of Writing, 144.

78 Cf. Rorty, "Philosophy as a Kind of Writing, 145.

79 Cf. Rorty, "Philosophy as a Kind of Writing, 145.

80 Cf. Rorty, "Philosophy as a Kind of Writing, 148. 
On the other hand, it is equally seriously conceded that that there are no persistent research problems for OT scholars to solve, since even these are given only in the context of the a particular theory whose assumptions tend to be generative of the concerns implied to be both valid and paramount. Yet without any serious research problems, the rationale and value of arguments or theses also disappear. 81 So what is one to do? Perhaps this is one reason why writing historical overviews is more prudent than doing the research about which such overviews are written.

The tension between Kantian and Hegelian philosophical assumptions in local historical overviews of South African OT scholarship cannot be resolved if the domain of discourse in which these assumptions are held includes or is moved over to "hermeneutics", "philosophy of history", "philosophy of language" or the "philosophy of literature". Not even distinguishing between natural and social sciences and further locating oneself in theology or the humanities, makes much of a difference in terms of wanting to both have one's cake (be critical realist in one's ontology) and eat it (be historicist in one's epistemology). The very idea that one can be "scientifically" concerned with the relations between words, texts and the supposed worlds behind, of or in front thereof is an incoherent notion.

To reduce the OT scholar's focus to a "philosophy of language" would, however, simply be the last resort of the Kantian influence in local historical constructions of the philosophical. It still involves the assumption that there is something eternally present for one to interpret (the structure of the world in the text, the ethics of interpretation and the nature of the text) and that a modification of method or ideology will let us see the facts more clearly (or make them more relevant to our contemporary cultural contexts). As such, it is hard to imagine the meta-philosophy in local western historical overviews as having really come to terms with itself as a kind of writing.

\section{E CONCLUSION}

In this study, the concept of philosophy was analysed as it appears in some of the more prominent historical overviews of local OT scholarship that were published in the post-apartheid era. From the analysis of histories of interpretation written between 1993 and 2017, it would seem that although the words "philosophy" and "philosophical" are found mainly in the context of OT hermeneutics, the second-order concepts, concerns and categories indicate the primary auxiliary philosophical sub-discipline to be the philosophy of science. Other philosophical sub-disciplines such as epistemology, ethics, philosophy of history and even philosophical hermeneutics seem to have been of interest only to the extent that

81 Cf. Rorty, "Philosophy as a Kind of Writing, 148. 
they allowed OT scholars to claim scientific status for their discipline in a manner that waylaid the different concerns from both within academia and outside this sphere.

Supervening on the construction of philosophy thus identified were shown to be the older systematic theological apologetic and polemical concerns regarding the relation between faith and reason, theology and philosophy and, ultimately, religion and science. Moreover, in opting for a critical-realist ontology, the pressures on the discipline from the Church on the one hand and the university context on the other could be relieved. It allowed OT scholars to present themselves as avoiding extreme views on the philosophical and theological spectrum, namely naïve realism and anti-realism, fundamentalism and radicalism, dogmatism and relativism, positivism and nihilism, antiintellectualism and scientism, among others.

The price of survival was that a middle ground could only be found as long as it was based on two incommensurable modern traditions in philosophy regarding its own purpose and task. On the one hand, the influence of the Kantian tradition demanded theories of representation, while on the other, Hegelian historical consciousness implied that this was a non-issue from the start. Consequently, it has now reached a point where it has become very important to devote oneself completely and in utmost seriousness to what may be referred to as research going nowhere, slowly. At best one could hope to become a name in a historical overview where how we missed the post-modern condition far outweighs the problem of having missed the Enlightenment. Such is currently the bearable heaviness of becoming a South African OT scholar.

To be pessimistic, however, would assume too much. In fact, only in the ruins of Kant's general theory about the relation between representations and their objects await new future avenues of genuinely local Old Testament interpretation. Here as elsewhere, now as always, the reading of the OT has been as much an art as a science, the dichotomy itself, of course, being a false one. So why not become so completely, for is not art as regards theory, history and practice part of academia too. Moreover, was it not the scientific understanding of the OT itself which showed us that we are not dealing with a textbook of science and insisted it should be understood on its own terms? Another conundrum, to be sure, but one which, instead of opening a door for a return to an outdated and harmful fundamentalist or colonialist hermeneutics, hints at the possibility of re-creating ourselves as South African OT aesthetics instead. 
318 Gericke, "Historical Overviews of SAOTS," OTE 31/2 (2018): 299-322

\section{BIBLIOGRAPHY}

Barr, James. The Concept of Biblical Theology. An Old Testament Perspective. Philadelphia: Fortress Press, 1999.

, History and Ideology in the Old Testament: Biblical Studies at the End of a Millennium. Oxford: Oxford University Press.

Boshoff, Piet B. 1987. Eksistensiële verstaan van die Ou Testament: Die teologiese arbeid van Antonius HJ Gunneweg. HTS Theological Studies/Teologiese Studies 43 (1987): 57-373. https://doi.org/10.4102/hts.v43i3.2251

Bosman, Hendrik L. "Modelle van Skrifuitleg: Samehang en verskil." Scriptura 19 (1986): 1-17.

."Wetenskapsteorie en inleidingswetenskap." Skrif en Kerk 8/2 (1987): 127-141. "The historical understanding of the Old Testament in South Africa: Colenso, Le Roux and Beyond." Verbum et Ecclesia 34/2 (2013) Art. \#793. https://doi.org/10.4102/ve.v34i2.793.

"Ants, spiders or bees . . . and ticks? A typology of Old Testament scholarship in South Africa since 1994 within its African context." Old Testament Essays 28/3 (2015a): 636-654. https://doi.org/10.17159/2312-3621/2015/v28n5a5

. The Hebrew Bible/Old Testament studies in Africa. Pages 253-268 in The Hebrew BiblelOld Testament. The History of its interpretation (Vol. 3). From modernism to post-modernism (The nineteenth and twentieth Century). Edited by Magne Saebo. Göttingen: Vandenhoeck \& Ruprecht, 2015b.

Baudrillard, Jean. Forget Foucault. Translated by Nicole Dufrense, introduction and interview by Sylvère Lotringer. Cambridge, MA: Semiotext(e), 2007 (1976).

Breytenbach, Andries P. B. "Departement Ou-Testamentiese Wetenskap." Pages 125127 in Ad Destinatum III 1983-1992. 'n Geskiedenis van die Universiteit van Pretoria. Edited by Johannes S. Bergh and Ockert, J. O. Ferreira. Pretoria: Tydskrif Universiteit van Pretoria, 1996.

Breytenbach, Andries. P. B. and Le Roux, Jurie H. "Old Testament studies." Pages 120-122 in Ad Destinatum IV 1993-2000. Historical developments and events at the University of Pretoria. Edited by Flip van der Watt. Pretoria: University of Pretoria, 2002.

Deist, Ferdinand E. "Ope vrae aan die diskoersanalise." Nederduits-Gereformeerde Teologiese (1978): 260-271.

. Historiese heuristiek, teologiese hermeneutiek en Skrifgesag. Port Elizabeth: Universiteit van Port Elizabeth. (Navorsingspublikasie C 11. 1979a.

" "Gedagtes oor die aard en moraliteit van wetenskaplike kennis." Theologia Evangelica 12/2 (1979b): 16-21.

. "Relatiwisme en absolutisme: Kan dit oorkom word? Oor "bybelse" en "dogmatiese" teologie." Pages 1-17 in Ou Testament Teologie: Gister, Vandag en More. Edited by Willem S. Prinsloo \& Wil Vosloo. Kaapstad. NG Kerk Uitgewers.

. "Bibelinterpretation und/als Ideologiekritik." Old Testament Essays 1 (1987b): 26-48. 
. "Naiewe realisme en Ou-Testamentiese wetenskap in die Nederduitse Gereformeerde Kerk." Pages 23-32 in In mensetaal oor God se Woord. Edited by Willem S. Prinsloo \& Wil Vosloo. Cape Town: Lux Verbi, 1988.

"Old Testament and modern historiography: On presuppositions and hermeneutics." Old Testament Essays 3(1) (1990): 7-22.

"South African Old Testament studies and the future." Old Testament Essays 7/4 (1994a): 33-51.

. Ervaring, rede en metode in Skrifuitleg: 'n Wetenskapsteoretiese ondersoek na Skrifuitleg in die Nederduits Gereformeerde Kerk 1840-1990. Pretoria: RGN, 1994b.

Deleuze, Giles and Guattari, Félix. What is Philosophy? Translated by Graham Birchill and Hugh Tomlinson. London and New York: Verso. 1994.

Gericke, Jaco. The Hebrew Bible and philosophy of religion. Resources in Biblical Literature 70. Atlanta: Society of Biblical Literature, 2012. https://doi.org/10. 2307/j.ctt32bzm3

. What is a God: Philosophical Perspectives on Divine Essence in the Hebrew Bible. London: Bloomsbury T \& T Clark, 2017.

Groenewald, Alphonso. "Once again methods: Is there a method in the madness?" Old Testament Essays 17/4 (2004): 544-559. https://doi.org/10.4102/hts.v63i3.231

. "Changing paradigms: Old Testament scholarship between synchrony and diachrony." Pages 108- 123 in South African perspectives on the Pentateuch between synchrony and diachrony. Edited by Jurie H. Le Roux \& Eckart Otto. T\&T Clark, New York, 2007.

Holter, Knut. Old Testament research for Africa: A critical analysis and annotated bibliography of African Old Testament dissertations, 1967ᄀ2000. New York: Peter Lang, 2002.

Human, Dirk J., Groenewald, Alphonso, Meyer, Esias E., Geyser-Fouché, Ananda, Ndoga, Sam S. \& De Villiers, Gerda. "Old Testament studies at the University of Pretoria: Glimpses of the past and Future. Art 1789 in Theology at the University of Pretoria - 100 years: (1917-2017). Past, Present and Future. Verbum et Ecclesia, Suppl. 2, 38(4) (2017).

Joll, Nicholas. "Contemporary metaphilosophy." No pages. The Internet Encyclopedia of Philosophy. Cited on 2 February 2018. Online: http://www.iep.utm.edu/.

Jonker, Louis C. "Why history matters: The place of historical consciousness in a multidimensional approach towards biblical interpretation." Verbum et Ecclesia 34/2 (2013):1-7 https://doi.org/10.4102/ve.v34i2.775

Lazerowitz, Morris. "A Note on 'Metaphilosophy." Metaphilosophy 1/1 (1970): 9191. https://doi.org/10.1111/j.1467-9973.1970.tb00792.x

Lategan, Bernard C. and Vorster, Willem S. Text and reality: aspects of reference in biblical texts. Philadelphia: Scholars Press. SBL Semeia Studies, 1985.

Le Roux, Jurie H. "Die departement Ou Testament, 'n halwe eeu oud." Skrif en Kerk 9/1 (1988): 160-180. . A story of two ways: Thirty years of Old Testament scholarship in South Africa. Pretoria: Verba Vitae, 1993.

. "Die Kontoere van 'n weerwoord." Verbum et Ecclesia 16/1 (1995): 82-101. https://doi.org/10.4102/ve.v16i1.441

. "Old Testament Studies: The Story of a Department." Verbum et Ecclesia 30/1 (2009): 1-9. https://doi.org/10.4102/ve.v30i3.182 
320 Gericke, "Historical Overviews of SAOTS," OTE 31/2 (2018): 299-322

" "Pro Pent: A project for the study of the Pentateuch in South Africa." HTS

Teologiese Studies/ Theological Studies 68/1 (2012): art 1277, 10 pages. https://doi.org/10.4102/hts.v68i1.1277

. 'Ou Testamentiese Studies." Pages 196-224 in Die Ned Geref Kerk en teologiese opleiding aan UP (1938-2013). Edited by Dirk J. Human and Johan van der Merwe. Pretoria: Kitskopie, 2013.

Lategan Bernard C. and Vorster, Willem S. 1985. Text and reality: aspects of reference in biblical texts. Philadelphia: Scholars Press. SBL Semeia Studies

Loader, James A. "The concept of revelation in Dutch ethical theology: its implications for Old Testament scholarship." Old Testament Essays 3 (1985): 18-32.

. "Interpreting the Old Testament in South Africa - exegesis, existential meaning and social relevance." Old Testament Essays 5 (1987): 24- 31.

. "Die weg van die Here in die woestyn, oftewel God se grootpad in die wildernis: oor A Story of Two Ways.” Skrif en Kerk 15/2 (1994): 391-413. https://doi.org/ 10.4102/ve.v15i2.1105

Lombaard, Christo J.S. "The relevance of Old Testament science in / for Africa: two false pieties and focussed scholarship." Old Testament Essays 19/1 (2006): 144155.

. "Of serpents, reeds, understanding, and turns. Some perspectives on implied apologetics and Pentateuch theory." Studia Historiae Ecclesiasticae 1/XXXIII (2007): 351-365.

. "Four recent works on the interpretation of the Old Testament in South Africa, with evaluation and some implications." Scriptura 78 (2013): 467-478. https://doi.org/10.7833/78-0-697

Masenya (ngwa'na Mphahele), Madipoane and Ramantswana, Hulisani. “Anything new under the sun of South African Old Testament scholarship? African Qoheleth's review of OTE 1994-2010." Old Testament Essays 25/3 (2012): 598637.

. "Anything new under the sun of African biblical hermeneutics in South African Old Testament scholarship? Incarnation, death and resurrection of the Word in Africa." Verbum et Ecclesia 36/1 (2015): 7 pages. https://doi.org/10.4102/ve. v36i1.1353

Meyer, Esias E. "South African Old Testament criticism: Squeezed between an ancient text and contemporary contexts." HTS Teologiese Studies/ Theological Studies 71/3 (2015): 1-7. https://doi.org/10.4102/hts.v71i3.2876

Moore, Steven D. and Sherwood, Yvonne. The invention of the biblical scholar. A critical manifesto. Syracuse: Syracuse University Press, 2008.

Mtshiselwa. Ndikho, "Towards an Indigenous (Xhosa) South African biblical scholarship." Old Testament Essays 24/3 (2011): 668-689.

Nel, Marius. "Pentecostals' reading of the Old Testament." Verbum et Ecclesia 28/2 (2007): 524-541. https://doi.org/10.4102/ve.v28i2.120

Nel, Philip J. "A critical Perspective on Old Testament exegetical methodology." Old Testament Essays 2/3 (1989): 64-74.

Rorty, Richard, Philosophy as a Kind of Writing: An Essay on Derrida, New Literary History, Vol. 10, No. 1, Literary Hermeneutics. (Autumn, 1978), pp. 141-160.

Rossouw, Hennie W. Wetenskap, interpretasie, wysheid. Port Elizabeth: Universiteit van Port Elizabeth, 1980. 
Sheehan, Jonathan. The Enlightenment Bible: Translation, Scholarship, Culture. Princeton: Princeton University Press. 2005.

Snyman, Fanie D. 'Some preliminary thoughts on epistemological transformation and the study of the Old Testament', Verbum et Ecclesia 34(2) (2013): Art. \#794, 5 pages. https://doi.org/10.4102/ve.v34i2.794 http://www.ve.org.za

Spangenberg, Izak J.J. "Paradigmaveranderinge in die bybelwetenskappe:'n Bydrae tot die gesprek tussen die bybelwetenskappe en sistematiese teologie." Religie \& Teologie 1/2 (1994): 144-184. https://doi.org/10.1163/157430194X00141

Swanepoel, Marius G. "Wetenskapsteorie, eksegetiese metodologie en Ou Testament teologie." HTS Teologiese Studies/ Theological Studies 46/1 (1990): 190-206. https://doi.org/10.4102/hts.v46i1/2.2305

Ukpong, Justin S. "Developments in biblical interpretation in Africa: Historical and hermeneutical directions." Pages 582-594 in The Bible in Africa: Transactions, Trajectories and Trends. Edited by Gerald O. West and Musa Dube. Leiden: E.J. Brill, 2000.

Van Deventer, Hans J.M. "'n Verband tussen die ontwikkelinge in filosofiese hermenetiek en ontwikkelinge in benaderings tot bybelinterpretasie." Koers 64/1 (1999): 393-413.

. "Pardon my paradigm: On the paradigmatic nature of methods and paradigm changes in biblical studies." Old Testament Essays 18/3 (2005): 847-862.

"Eerder anders as elders: Gerrie Snyman se bydrae in die konteks van die Gereformeerde teologie." Verbum et Ecclesia 31(1), Art. \#306, 7 pages. https://doi.org/10.4102/ids.v46i2.58

Van Heerden, Willie, S. Die interpretasie van die boek Jona in die Nederduitse Gereformeerde Kerk: 'n Hermeneutiese studie. DTh-Proefskrif, Pretoria: Unisa 1988.

. "Taking Stock of Old Testament scholarship on environmental issues in South Africa: The main contributions and challenges." Old Testament Essays 22/3 (2009): 695-718.

Van Huyssteen, Wentzel J.V. "Understanding Religious Texts: The Role of Models in Biblical Interpretation.” Old Testament Essays 5 (1987): 9-23.

Truth and commitment in theology and science: An appraisal of Wolfhart Pannenberg's perspective. HTS 45 (1989): 99-116.

Van Rooy, Herrie F. "Die Bydrae en Relevansie van die Ou-Testamentiese etenskapsbeoefening in die Gereformeerde Kerke in Suid-Afrika (1869-1994)." In die Skriflig 29/1 (1995): 47-76.

Venter, Rian. "Theology and the (post-)apartheid university: Mapping discourses, interrogating transformation." Transformation in Higher Education 1/1 (2016): 1-6. https://doi.org/10.4102/the.v1i1.5

Vorster, Johannes H. "Exploring similarities between the German and the Dutch ethical traditions: Possibilities of the history of religion for a theological approach to Old Testament studies in South Africa." HTS Teologiese Studies/Theological Studies 66(1), Art. \#428 (2010): 12 pages. https://doi.org/10.4102/hts.v66i1.428

West, Gerald O. "Shifting perspectives in the comparative paradigm in (South)-African biblical scholarship." Religion and Theology 12/1 (2005): 48-72. https://doi.org/10.1163/157430105X00121

The stolen Bible: From tool of imperialism to African icon. Leiden/Boston: Brill, 2016. https://doi.org/10.1163/9789004322783 
322 Gericke, "Historical Overviews of SAOTS," OTE 31/2 (2018): 299-322

West, Gerald O. and Dube, Musa. The Bible in Africa: Transactions, trajectories and trends. Leiden: E.J. Brill, 2000.

Williamson, Timothy. The Philosophy of Philosophy. Malden MA and Oxford: Blackwell, 2007. https://doi.org/10.1002/9780470696675

Jaco Gericke, Ancient Texts and Culture, Faculty of Theology, North-West

University, Email: 21609268@nwu.ac.za. ORCID ID: https://orcid.org/00000002-1304-7751 